\title{
DYNAMICS OF ORGANIC C MINERALIZATION AND THE MOBILE FRACTION OF HEAVY METALS IN A CALCAREOUS SOIL INCUBATED WITH ORGANIC WASTES
}

\author{
A. R. A. USMAN*, Y. KUZYAKOV and K. STAHR \\ Institute of Soil Science and Land Evaluation (310), University of Hohenheim, \\ D-70593 Stuttgart, Germany \\ (*author for correspondence,e-mail: adel@uni-hohenheim.de, Fax: +49-711-459-3117, \\ Tel: +49-711-459-3383)
}

(Received 18 February 2004; accepted 14 May 2004)

\begin{abstract}
Organic wastes such as sewage sludge and compost increase the input of carbon and nutrients to the soil. However, sewage sludge-applied heavy metals, and organic pollutants adversely affect soil biochemical properties. Therefore, an incubation experiment lasting 90 days was carried out to evaluate the effect of the addition of two sources of organic $\mathrm{C}$ : sewage sludge or composted turf and plant residues to a calcareous soil at three rates $\left(15,45\right.$, and $90 \mathrm{t}$ of dry matter ha $\left.{ }^{-1}\right)$ on $\mathrm{pH}$, $\mathrm{EC}$, dissolved organic $\mathrm{C}$, humic substances $\mathrm{C}$, organic matter mineralization, microbial biomass $\mathrm{C}$, and metabolic quotient. The mobile fraction of heavy metals $(\mathrm{Zn}, \mathrm{Cd}, \mathrm{Cu}, \mathrm{Ni}$, and $\mathrm{Pb}$ ) extracted by $\mathrm{NH}_{4} \mathrm{NO}_{3}$ was also investigated.

The addition of sewage sludge decreased soil $\mathrm{pH}$ and increased soil salinity to a greater extent than the addition of compost. Both sewage sludge and compost increased significantly the values of the cumulative $\mathrm{C}$ mineralized, dissolved organic $\mathrm{C}$, humic and fulvic acid $\mathrm{C}$, microbial biomass $\mathrm{C}$, and metabolic quotient $\left(q \mathrm{CO}_{2}\right)$, especially with increasing application rate. Compared to compost, the addition of sewage sludge caused higher increases in the values of these parameters. The values of dissolved organic $\mathrm{C}$, fulvic acid $\mathrm{C}$, microbial biomass $\mathrm{C}$, metabolic quotient, and $\mathrm{C} / \mathrm{N}$ ratio tended to decrease with time. The soil treated with sewage sludge showed a significant increase in the mobile fractions of $\mathrm{Zn}, \mathrm{Cd}, \mathrm{Cu}$, and $\mathrm{Ni}$ and a significant decrease in the mobile fraction of $\mathrm{Pb}$ compared to control. The high application rate of compost resulted in the lowest mobility of $\mathrm{Cu}, \mathrm{Ni}$, and $\mathrm{Pb}$. The results suggest that biochemical properties of calcareous soil can be enhanced by both organic wastes. But, the high salinity and extractability of heavy metals, due to the addition of sewage sludge, may limit the application of sewage sludge.
\end{abstract}

Keywords: biochemical properties, calcareous soil, compost, heavy metals, humic substances C, sewage sludge

\section{Introduction}

The soils of arid and semiarid regions low in organic $\mathrm{C}$ content need organic amendments to improve their physicochemical and biological properties and thus their productivity and natural fertility (Pascual et al., 1997). The most widely used organic amendments are sewage sludge and compost, which have high organic matter, $\mathrm{N}$ and $\mathrm{P}$ contents, making them suitable for agricultural purposes. However, the use of sewage sludge as agricultural fertilizer has raised numerous environmental and

Water, Air, and Soil Pollution 158: 401-418, 2004.

(c) 2004 Kluwer Academic Publishers. Printed in the Netherlands. 
health issues because of the significant concentrations of toxic metals, organic compounds, and pathogens commonly found in these waste materials (McBride et al., 1997; Moreno et al., 1999; Berrow and Webber, 1972). Soil quality is a complex characteristic, and is determined by the physical, chemical, and biological components of the soil (Johansson et al., 1999). Changes in soil biochemical characteristics may be good indicators of soil quality, since they are more dynamic and often more sensitive than physical or chemical soil properties (Friedel et al., 2000). Such information is required to detect any possible toxicities resulting from the use of sewage sludge and as an indicator of soil rehabilitation. Pascual et al. (1997) demonstrated that the addition of urban organic wastes (municipal solid wastes, sewage sludge and compost) to the soil increases the values of biomass carbon, basal respiration, biomass $\mathrm{C} /$ total organic $\mathrm{C}$ ratio, and metabolic quotient $\left(q \mathrm{CO}_{2}\right)$, indicating the activation of soil microorganisms. It is evident, that heavy metals introduced with sewage sludge or compost cause accumulation of organic matter and decrease the turnover rate of organic matter, presumably because of inhibitory effects on the microbial biomass (Leita et al., 1995, 1999; Chander et al., 1995; Chander and Brookes, 1991). Moreno et al. (1999) found that the addition of cadmium-contaminated sewage sludge compost to the soil decreased microbial biomass $\mathrm{C}$ and stimulated the metabolic activity of the microbial biomass. The addition of sewage sludge to soils could affect the potential availability of heavy metals (Wang et al., 1997). Mineralization of sludge organic matter may release heavy metals into more soluble forms that may harm sensitive crops and microbes (McBride, 1995). The availability of heavy metals in the sewage sludge and soils treated with sewage sludge depends on many factors such as the properties and amount of heavy metal, the partitioning of heavy metals between solution and solid phase, and soil characteristics (Jin et al., 1996). It is widely known that the bioavailability of heavy metals in soil is strongly influenced by the amount and the quality of organic matter that can react with the heavy metals, forming complexes and chelates of varying stability (Leita et al., 1999). Soil organic matter is quite effective in retaining heavy metals. Heavy metal-organic associations can occur both in soil solution and at the solid surfaces of either native soil constituents or any added material (e.g., biosolids) (Silveira et al., 2003). In a heavy metal-polluted soil, Kiikilä et al. (2002) studied the effect of biosolids as organic immoblizing agents and observed that the exchangeable $\mathrm{Cu}$ concentration decreased. On the other hand, the heavy metal could be complexed by dissolved organic matter (DOC), which enhances leaching in the field (Moolenaar and Beltrami, 1998).

The aim of this work was to study the effects of increasing rates of two sources of organic matter: sewage sludge and compost applied to an Egyptian calcareous soil on $\mathrm{pH}, \mathrm{EC}$, water-dissolved organic $\mathrm{C}$, humic substances $\mathrm{C}$, microbial biomass $\mathrm{C}$, metabolic quotient, organic matter mineralization, and $\mathrm{C} / \mathrm{N}$ ratio. Additionally, the extractability of mobile heavy metals $(\mathrm{Zn}, \mathrm{Cd}, \mathrm{Cu}, \mathrm{Ni}$, and $\mathrm{Pb}$ ) was investigated. 


\section{Material and Methods}

For the incubation experiment an Egyptian calcareous soil low in organic $\mathrm{C}(0.31 \%)$ and high in $\mathrm{CaCO}_{3}$ content $(15.9 \%)$ was used. The particle size distribution was $86.8 \%$ sand, $3.5 \%$ clay, and $9.7 \%$ silt. The $\mathrm{pH}$ of the soil was 8.16 and electrical conductivity was $2.90 \mathrm{dS} \mathrm{m}^{-1}$. Two sources of organic matter (sewage sludge and compost) were added to this soil, the main characteristics of which are described in Table I. The sewage sludge was collected from the Plieningen sewage treatment plant, Germany. The compost used was prepared by 3-year free air composting of turf and plant residues, which were collected from field and greenhouse. Both sewage sludge and compost were added to the soil at rates of 15, 45, and 90 tonnes of dry matter per hectare. The soil-sludge or compost mixtures $(50 \mathrm{~g})$ were put in glass vessels $(250 \mathrm{~mL})$, the experiment being carried out in triplicate. Distilled water was added to each soil mixture to bring it to $70 \%$ of its water-holding capacity. An unamended soil was used as the control. Small vials with $5 \mathrm{~mL}$ of $1 \mathrm{M} \mathrm{NaOH}$ solution were placed in the vessels for trapping $\mathrm{CO}_{2}$. After the addition of $\mathrm{NaOH}$, the vessels were closed air tight and incubated at $35^{\circ} \mathrm{C}$. This temperature was chosen, because it is the average temperature in the South of Egypt in summer time. The $\mathrm{NaOH}$ solution in the vials was changed after $0,6,15,27,43,60$, 76 , and 90 days. For day 0 , the $\mathrm{NaOH}$ solution in the vials was changed after $1 \mathrm{~h}$.

Soil $\mathrm{pH}$ and electrical conductivity (EC) were measured with a glass electrode using a soil-to-water ratio of $1: 1$. The $\mathrm{pH}$ and electrical conductivity of sewage sludge and compost were measured using a ratio of 1:10. The soil texture was determined by means of the pipette method (Schlichting et al., 1995).

After 0,27, 60, and 90 days of incubation, the soil was destructively sampled, and the mobile fraction of $\mathrm{Zn}, \mathrm{Cd}, \mathrm{Cu}, \mathrm{Ni}$, and $\mathrm{Pb}$ was measured after extraction of

TABLE I

Characteristics of soil and organic wastes

\begin{tabular}{lccc}
\hline Characteristics & Soil & Sewage sludge & Compost \\
\hline $\mathrm{pH}\left(\mathrm{H}_{2} \mathrm{O}\right)$ & 8.16 & 5.9 & 7.8 \\
Ec $\left(\mathrm{dS} \mathrm{m}^{-1}\right)$ & 2.9 & 1.9 & 0.4 \\
Total organic C $(\%)$ & 0.31 & 22.7 & 9.8 \\
Total N (\%) & 0.021 & 3.5 & 0.6 \\
$\mathrm{C} / \mathrm{N}$ & 14.8 & 6.5 & 16.3 \\
$\mathrm{Zn}\left(\mathrm{mg} \mathrm{kg}^{-1}\right)$ & 22.1 & 1014 & 126 \\
$\mathrm{Cd}\left(\mathrm{mg} \mathrm{kg}^{-1}\right)$ & 0.38 & 4.5 & 0.7 \\
$\mathrm{Cu}\left(\mathrm{mg} \mathrm{kg}^{-1}\right)$ & 17.5 & 402 & 38 \\
$\mathrm{Ni}\left(\mathrm{mg} \mathrm{kg}^{-1}\right)$ & 7.7 & 104 & 19 \\
$\mathrm{~Pb}\left(\mathrm{mg} \mathrm{kg}^{-1}\right)$ & 6.5 & 230 & 23 \\
\hline
\end{tabular}


2-g air-dry soil with $50 \mathrm{~mL}$ of $\mathrm{NH}_{4} \mathrm{NO}_{3}$ for $2 \mathrm{~h}$ (Schlichting et al., 1995). The total content of $\mathrm{Zn}, \mathrm{Cd}, \mathrm{Cu}$ and $\mathrm{Ni}$ was determined by an aqua regia microwave digestion method. Heavy metal concentrations were determined by atomic-absorption spectrometry (AAS Perkin Elmer 3100).

All forms of extracted $\mathrm{C}$ were measured after 0,27,60, and 90 days of incubation. Dissolved organic C (DOC) was measured in an aqueous extract (1:10). The humic substances $\mathrm{C}$ were extracted by $0.1 \mathrm{M} \mathrm{Na}_{4} \mathrm{P}_{2} \mathrm{O}_{7}$ at a solid/liquid ratio of $1: 10$. The fulvic acid $\mathrm{C}$ was measured after the precipitation of the humic acid $\mathrm{C}$ at pH 2.0 from the Na pyrophosphate extract. The humic acid $\mathrm{C}$ was calculated by subtracting the fulvic acid $\mathrm{C}$ from $\mathrm{C}$ extracted by $0.1 \mathrm{M}$ Na pyrophosphate. Soil microbial biomass $\mathrm{C}$ was measured by the fumigation-extraction method (Vance et al., 1987). In this technique, three replicates of each treatment were fumigated with ethanol-free chloroform for $24 \mathrm{~h}$ at $25^{\circ} \mathrm{C}$. Then the soil samples were extracted with $0.5 \mathrm{M} \mathrm{K}_{2} \mathrm{SO}_{4}$ for $30 \mathrm{~min}$. Three replicates of non-fumigated soil samples were extracted similarly. All extracted forms of $\mathrm{C}$ were determined by an automated procedure, using a DIMA-TOC 100 carbon analyzer. Microbial biomass $\mathrm{C}$ was calculated as $\mathrm{Ec} / \mathrm{kEC}$, where $\mathrm{Ec}$ is organic $\mathrm{C}$ extracted from fumigated soils minus organic $\mathrm{C}$ extracted from non-fumigated soils and the $\mathrm{kEC}=0.45$ (Jörgensen, 1996; Wu et al., 1990).

$\mathrm{CO}_{2}$ evolved during the incubation was trapped in $1 \mathrm{M} \mathrm{NaOH}$ and the excess of $\mathrm{NaOH}$ was titrated with $0.1 \mathrm{M} \mathrm{HCl}$ after addition of $\mathrm{BaCl}_{2}$ (Black, 1965). Mineralized $\mathrm{C}$ was calculated as cumulative $\mathrm{CO}_{2}$-evolution ( $\mathrm{g} \mathrm{kg}^{-1}$ soil) (Leifeld et al., 2002). The specific respiration activity $\left(q \mathrm{CO}_{2}\right)$ was expressed as the production of $\mathrm{CO}_{2}-\mathrm{C}$ per unit microbial biomass $\mathrm{C}$ and time (Anderson and Domsch, 1978).

For control soil and soil treated with organic amendments, total soil $\mathrm{C}$ and $\mathrm{N}$ were measured by LECO $2000 \mathrm{CN}$ analyser after $0,27,60$, and 90 days of incubation. The soil inorganic carbon was determined with a Scheibler apparatus (carbonates were dissolved with $10 \% \mathrm{HCl}$ and the volume of released $\mathrm{CO}_{2}$ was measured). After that, the carbonate concentrations were calculated using the universal Gas Law (Schlichting et al., 1995). In the soil samples, total organic carbon (TOC) was calculated as differences between total carbon and inorganic carbon.

Differences of means between treatments were tested by separate two-way ANOVAs and subsequent post-hoc comparisons of means (LSD test, at $P=0.05$ ).

\section{Results and Discussion}

\subsection{EFFECT OF ORGANIC WASTES AND INCUBATION TIME ON DYNAMICS OF $\mathrm{pH}$ and EC}

For all treatments, soil $\mathrm{pH}$ was alkaline (7.5-8.2) during the incubation (Table II). The highest application rate of sewage sludge and compost $\left(90 \mathrm{tha}^{-1}\right)$ led to a 
TABLE II

Effect of organic wastes on dynamics of soil $\mathrm{pH}$ during the incubation experiment

\begin{tabular}{|c|c|c|c|c|c|}
\hline \multirow{2}{*}{$\begin{array}{l}\text { Application } \\
\text { rate }\left(\mathrm{t} \mathrm{ha}^{-1}\right)\end{array}$} & \multicolumn{5}{|c|}{ Incubation time (days) } \\
\hline & 0 & 27 & 60 & 90 & LSD \\
\hline \multicolumn{6}{|c|}{ Compost treatments } \\
\hline 15 & 8.14 & 8.17 & 8.18 & 8.19 & 0.05 \\
\hline 45 & 8.06 & 8.09 & 8.14 & 8.16 & 0.06 \\
\hline 90 & 7.96 & 7.95 & 8.02 & 8.02 & 0.08 \\
\hline \multicolumn{6}{|c|}{ Sewage sludge treatments } \\
\hline 15 & 8.05 & 7.95 & 7.94 & 7.95 & 0.09 \\
\hline 45 & 7.83 & 7.80 & 7.76 & 7.76 & 0.13 \\
\hline 90 & 7.59 & 7.63 & 7.60 & 7.54 & 0.09 \\
\hline \multicolumn{6}{|c|}{ Control treatments } \\
\hline- & 8.16 & 8.19 & 8.20 & 8.20 & 0.05 \\
\hline \multicolumn{6}{|c|}{ LSD treatments } \\
\hline & 0.10 & 0.08 & 0.05 & 0.07 & \\
\hline
\end{tabular}

significant decrease in $\mathrm{pH}$ of approximately $(0.55-0.66)$, and $(0.18-0.24)$ units, respectively. The lowest $\mathrm{pH}$ values were found for soil treated with sewage sludge at the application rate of $90 \mathrm{tha}^{-1}$. This decrease of soil $\mathrm{pH}$ is due to the acid effect of decomposable products of organic wastes, especially for sewage sludge. Speir et al. (2003) found that high application rates of sewage sludge to a light-textured sandy soil resulted in marked acidification in the zone of sludge incorporation $(0-20 \mathrm{~cm})$. Our results showed that $\mathrm{pH}$ varied little throughout the incubation period.

The addition of sewage sludge raised the soil salinity level more than the addition of compost (Table III). The soil salinity increased with increasing application rate of organic wastes. The highest increase in soil salinity level was found for soil treated with sewage sludge at the application rate of $90 \mathrm{tha}^{-1}$. At the beginning of the experiment (day 0), only the addition of sewage sludge at application rates of 45 and $90 \mathrm{t} \mathrm{ha}^{-1}$ raised the soil salinity level significantly, as compared to the control soil. But, with increasing incubation time, the addition of sewage sludge at all rates and compost at $90 \mathrm{t} \mathrm{ha}^{-1}$ raised the soil salinity level significantly, mainly as a result of the ions released during the organic matter mineralization process. Wong et al. (2001) found that the EC of soil increased significantly due to the addition of sewage sludge. Moreno et al. (1999) observed that the addition of sewage sludge compost to an arid soil increased the electrical conductivity of the soil. In fact, high salinity is one of the factors limiting plant growth in soil (Richards, 1960). 
TABLE III

Effect of organic wastes on dynamics of electrical conductivity during the incubation experiment

\begin{tabular}{|c|c|c|c|c|c|}
\hline \multirow{2}{*}{$\begin{array}{l}\text { Application } \\
\text { rate }\left(\mathrm{t} \mathrm{ha}^{-1}\right)\end{array}$} & \multicolumn{5}{|c|}{ Incubation time (days) } \\
\hline & 0 & 27 & 60 & 90 & LSD \\
\hline \multicolumn{6}{|c|}{ Compost treatment } \\
\hline 15 & 2.93 & 2.97 & 2.98 & 2.96 & 0.15 \\
\hline 45 & 2.96 & 2.98 & 2.98 & 2.98 & 0.16 \\
\hline 90 & 2.98 & 3.14 & 3.12 & 3.24 & 0.08 \\
\hline \multicolumn{6}{|c|}{ Sewage sludge treatment } \\
\hline 15 & 2.95 & 3.38 & 3.61 & 3.70 & 0.16 \\
\hline 45 & 3.20 & 3.67 & 4.10 & 5.00 & 0.07 \\
\hline 90 & 3.66 & 4.77 & 5.78 & 5.85 & 0.10 \\
\hline \multicolumn{6}{|c|}{ Control treatment } \\
\hline- & 2.94 & 2.96 & 2.97 & 2.97 & 0.17 \\
\hline \multicolumn{6}{|c|}{ LSD treatment } \\
\hline & 0.15 & 0.12 & 0.10 & 0.12 & \\
\hline
\end{tabular}

\subsection{EFFECT OF ORGANIC WASTES AND INCUBATION TIME ON DYNAMICS OF DOC AND HUMIC SUBSTANCES C}

Higher concentrations of dissolved organic $\mathrm{C}$ (DOC) were found in the soil treated with sewage sludge at all application rates (Figure 1). Land application of sewage sludge at agronomic rates increases dissolved organic carbon concentrations in soils (Sloan and Basta, 1995). The results showed that DOC decreased with increasing incubation time, mainly attributed to dissolved organic $\mathrm{C}$ being mineralized by microorganisms (Moreno et al., 1999).

The addition of sewage sludge and compost increased significantly humic substances $\mathrm{C}$ (humic and fulvic acid C) compared to the control (Figure 1). The fulvic and humic acid $\mathrm{C}$ increased significantly with increasing application rate of sewage sludge and compost. During the incubation experiment, the highest increases of fulvic and humic acid $\mathrm{C}$ were found for soil treated with sewage sludge at $90 \mathrm{tha}^{-1}$. In soil treated with sewage sludge, the fulvic acid $\mathrm{C}$ decreased as incubation time increased. This result is explained by a high proportion of easily biodegradable organic compounds in this fraction. In contrast, the humic acid $\mathrm{C}$ increased significantly with time, demonstrating the humification and polymerization of sludge organic matter. However, in soil treated with compost, the fulvic and humic acid $\mathrm{C}$ did not change significantly with time. This result indicates that the fulvic and humic acid $\mathrm{C}$ of compost are more stable as a result of long-time of composting process (3 years). 


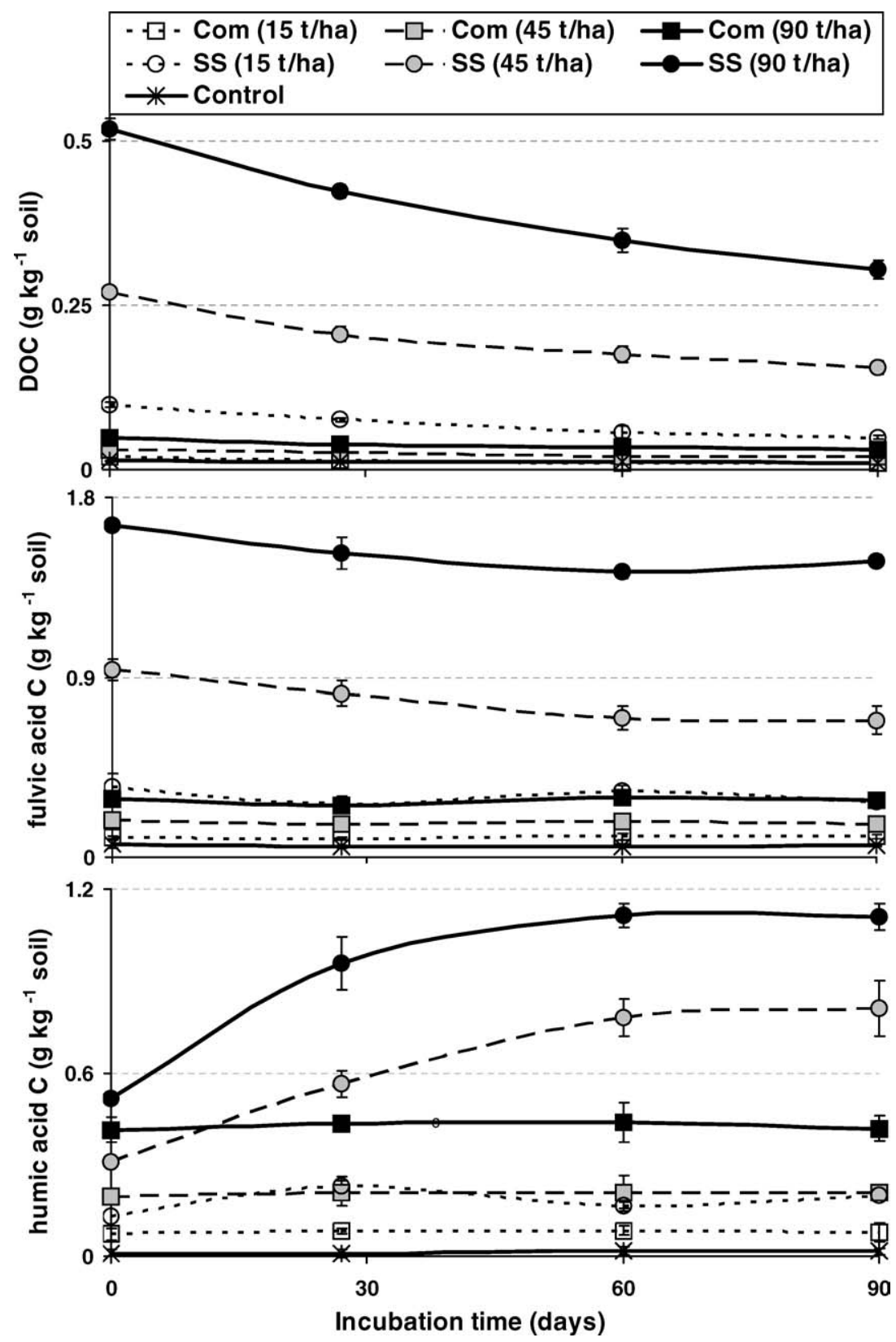

Figure 1. Effect of organic wastes on dynamics of dissolved organic carbon (DOC) and humic substances $\mathrm{C}$ during the incubation experiment. Control soil; (com) soil treated with compost at application rates of 15,45 , and $90 \mathrm{t} \mathrm{ha}^{-1}$; (SS) soil treated with sewage sludge at application rates of 15, 45, and $90 \mathrm{t} \mathrm{ha}^{-1}$. Average \pm S.D.; where absent, bars fall within symbols. 


\subsection{EFFECT OF ORGANIC WASTES AND INCUBATION TIME ON DYNAMICS

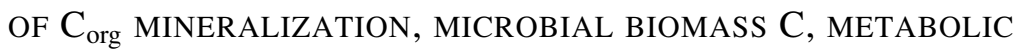 QUOTIENT, AND C/N RATIO}

The $\mathrm{C}_{\text {org }}$ mineralization during the experiment was recorded as cumulative $\mathrm{CO}_{2}$ evolution ( $\mathrm{g} \mathrm{kg}^{-1}$ soil). The addition of sewage sludge and compost led to a significant increase in $\mathrm{C}_{\text {org }}$ mineralization compared to unamended soil (Figure 2). The cumulative amount of $\mathrm{C}$ mineralized increased with increasing application rate of sewage sludge and compost. The highest $\mathrm{C}_{\text {org }}$ mineralization was found for sewage sludge. During the three months of incubation, the cumulative $\mathrm{C} \mathrm{min-}$ eralized amounted to $0.23,1.28$, and $2.93 \mathrm{~g} \mathrm{~kg}^{-1}$ soil for control soil, compost $\left(90 \mathrm{tha}^{-1}\right)$, and sewage sludge $\left(90 \mathrm{tha}^{-1}\right)$, respectively. The high loss of organic $\mathrm{C}$ by mineralization in sewage sludge amended soil could have been due to the high microbial activity as a consequence of the high concentration of dissolved organic $\mathrm{C}$ introduced with sewage sludge. The dissolved organic $\mathrm{C}$ is the most important source of energy for microorganisms. Pascual et al. (1999) attributed the high microbial activity in municipal waste-amended soil to the high level of water-soluble $\mathrm{C}$ of amended soil.

Before incubation, the $\mathrm{C} / \mathrm{N}$ ratios of sewage sludge and compost were 6.5 and 16.3 , respectively (Table I). These values are below 20, which is commonly accepted as a threshold for net $\mathrm{N}$ mineralization from organic residues. Among two organic wastes, sewage sludge application significantly decreased the initial $\mathrm{C} / \mathrm{N}$ ratio of the soil compared to the control (Table IV), mainly due to much lower $\mathrm{C} / \mathrm{N}$ ratio of sewage sludge than that of the compost. As incubation time progressed, the $\mathrm{C} / \mathrm{N}$ ratio of the soil significantly decreased also in compost treatments compared to the control. For the soil treated with organic wastes, the $\mathrm{C} / \mathrm{N}$ ratios tended to decrease significantly with time. This result attributed to soil organic matter mineralization and decrease of total organic $\mathrm{C}$ with time.

The soil microbial biomass $\mathrm{C}$ was used as a sensitive indicator of changing soil conditions (Leita et al., 1999). The addition of both organic wastes (sewage sludge and compost) caused a significant increase in microbial biomass $C$ (Figure 3). This result is explained by the increased number of microorganisms after addition of organic wastes (Goyal et al., 1993; Pascual et al., 1997). The soil microbial biomass $\mathrm{C}$ declined during the three months of incubation. This result suggested that the easily biodegradable pool of organic $\mathrm{C}$ was gradually exhausted. Chander et al. (1995) found that the soil microbial biomass C increased after sewage sludge addition and this initial increase of biomass $\mathrm{C}$ declined with prolonged incubation.

Microbial biomass $\mathrm{C}$ as a percentage of total organic $\mathrm{C}$ has been proposed as a sensitive indicator of changes in organic matter and it has also been used effectively to follow the state of a soil's organic matter content after the addition of organic materials (Pascual et al., 1997). Generally, the application of organic matter to the soil causes an increase in the ratio of microbial biomass/TOC (Powlson et al., 1987). In the control soil, the ratio of microbial biomass C/TOC ranged between 


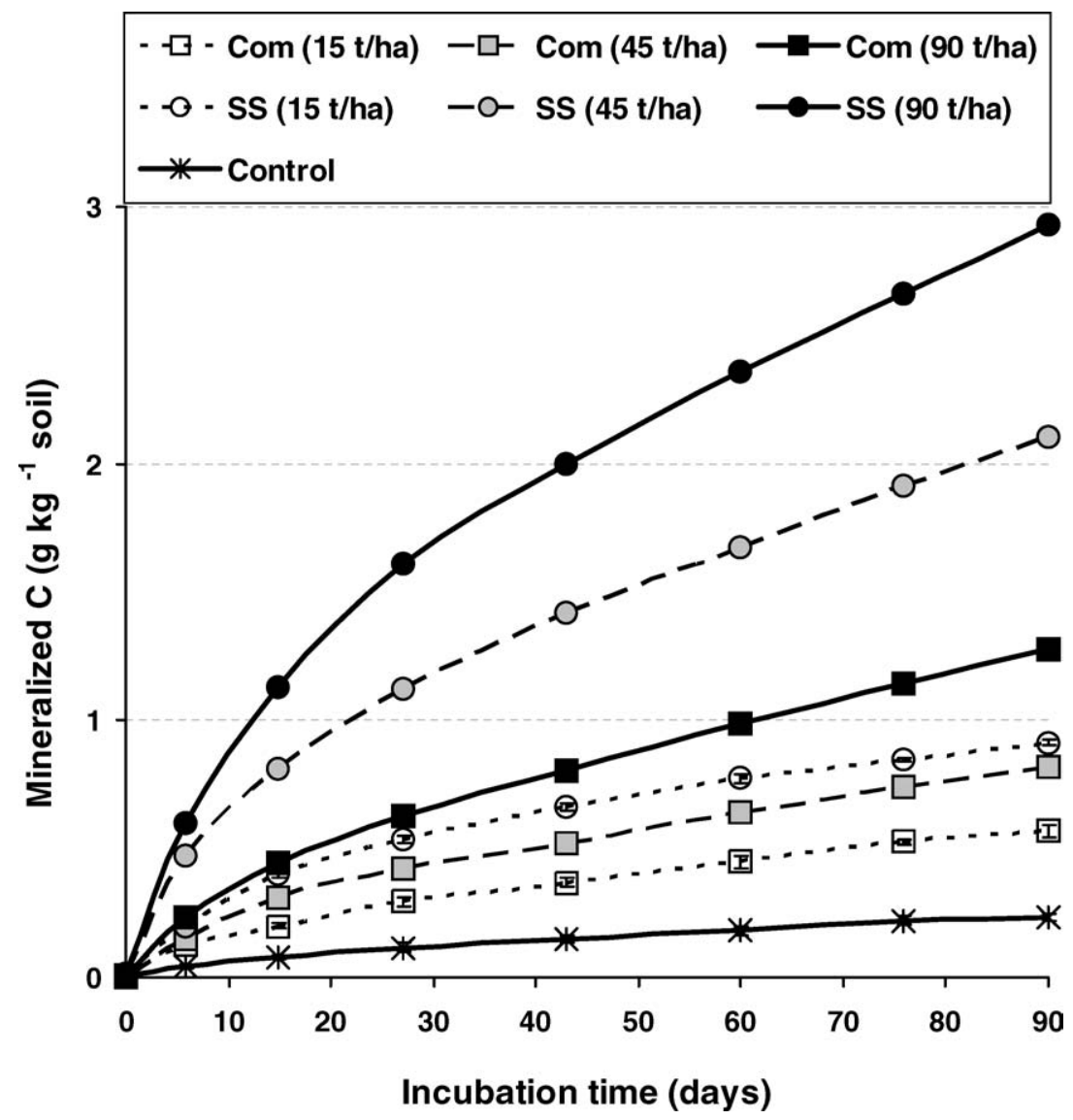

Figure 2. Effect of organic wastes on the cumulative amount of $\mathrm{C}$ mineralized during the incubation experiment. Control soil; (com) soil treated with compost at application rates of 15, 45, and $90 \mathrm{tha}^{-1}$; (SS) soil treated with sewage sludge at application rates of 15, 45, and $90 \mathrm{t} \mathrm{ha}^{-1}$. Average \pm S.D.; where absent, bars fall within symbols.

0.93 and 1.57 during the incubation time (Figure 3). The addition of both organic wastes caused a significant increase in this ratio, indicating a high availability of organic matter to soil microorganisms (Chander et al., 2001). This ratio decreased significantly as incubation time increased. This result concurs with that of Pascual et al. (1997) who found that the values of microbial biomass C/TOC in the soil amended with various urban wastes decreased with incubation time. The soil treated with sewage sludge showed a high decrease in microbial biomass $\mathrm{C}$ and biomass $\mathrm{C} / \mathrm{TOC}$ during the incubation experiment. This result indicates greater availability of the mineralizable material at the beginning and stabilization of sludge organic matter with increase of incubation time. Of the two organic wastes, the addition of sewage sludge at any application rate caused the higher initial values of biomass $\mathrm{C}$ and biomass $\mathrm{C} / \mathrm{TOC}$. However, as incubation time increased, these values of biomass $\mathrm{C}$ 
TABLE IV

\begin{tabular}{|c|c|c|c|c|c|}
\hline \multirow{2}{*}{$\begin{array}{l}\text { Application } \\
\text { rate }\left(\mathrm{t} \mathrm{ha}^{-1}\right)\end{array}$} & \multicolumn{5}{|c|}{ Incubation time (days) } \\
\hline & 0 & 27 & 60 & 90 & LSD \\
\hline \multicolumn{6}{|c|}{ Compost treatment } \\
\hline 15 & 14.1 & 13.2 & 12.4 & 12.0 & 0.9 \\
\hline 45 & 13.1 & 12.0 & 11.0 & 10.8 & 1.5 \\
\hline 90 & 13.7 & 12.4 & 11.5 & 10.8 & 0.9 \\
\hline \multicolumn{6}{|c|}{ Sewage sludge treatment } \\
\hline 15 & 9.0 & 8.0 & 7.6 & 7.3 & 0.8 \\
\hline 45 & 8.0 & 6.6 & 5.9 & 5.5 & 0.5 \\
\hline 90 & 7.5 & 6.2 & 5.6 & 5.3 & 0.6 \\
\hline \multicolumn{6}{|c|}{ Control treatment } \\
\hline- & 14.4 & 13.8 & 13.8 & 13.7 & 1.1 \\
\hline \multicolumn{6}{|c|}{ LSD treatment } \\
\hline & 1.1 & 0.8 & 1.0 & 0.6 & \\
\hline
\end{tabular}

and biomass C/TOC in sewage sludge amended soil decreased and reached values within the range of those in compost amended soil. For both organic wastes, the values of microbial biomass $\mathrm{C}$ and biomass $\mathrm{C} / \mathrm{TOC}$ were still significantly higher than those of the control soil at the end of the incubation.

The metabolic quotient $\left(q \mathrm{CO}_{2}\right)$ is a relationship between soil respiration and microbial biomass and is expressed as $\mathrm{mg} \mathrm{CO}_{2}-\mathrm{C} \mathrm{h}^{-1} \mathrm{~g}^{-1}$ microbial biomass $\mathrm{C}$ (Anderson and Domsch, 1978). The metabolic quotient is related to the hypothesis of energy optimization and it can be used as an indicator of environmental stress since it is calculated from parameters which are very sensitive to environmental changes (Anderson and Domsch, 1993). At the beginning of the experiment (day 0 ), the control soil had an initial metabolic quotient value of $7.8 \mathrm{mg} \mathrm{CO}_{2}-\mathrm{C} \mathrm{h}^{-1} \mathrm{~g}^{-1}$ biomass $\mathrm{C}($ Table $\mathrm{V})$. This value increased significantly due to the addition of sewage sludge at all application rates and compost at the high application rate. The highest increase of the metabolic quotient was found in sewage sludge-amended soil, mainly due to the high proportion of easily biodegradable compounds in sewage sludge. In all treatments, the values of the metabolic quotient decreased with incubation time, indicated by the lower $\mathrm{CO}_{2}$ evolution per biomass unit. During the three months of incubation, in the soil amended with sewage sludge at 45 and $90 \mathrm{t} \mathrm{ha}^{-1}$, the values of the metabolic quotient always remained significantly higher than those of the control and soil amended with compost. Leita et al. (1999) reported that the increase of metabolic activity occurred by the addition of municipal refuse compost may have been due to stress induced by heavy metals, even if these were below toxic levels. Although the initial value of metabolic activity increased significantly 


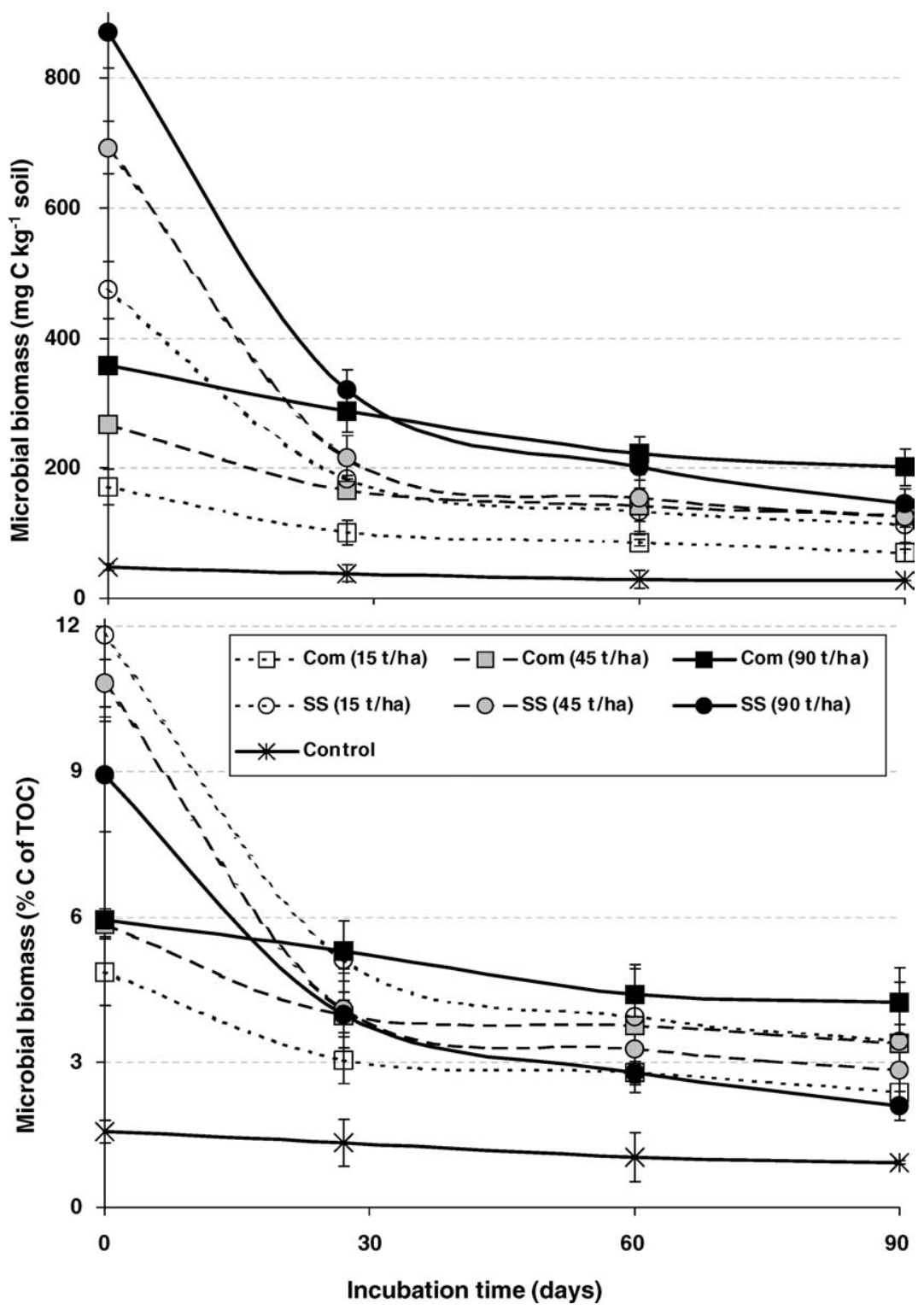

Figure 3. Effect of organic wastes on dynamics of microbial biomass $\mathrm{C}$ and microbial biomass $\mathrm{C} / \mathrm{TOC}$ during the incubation experiment. Control soil; (com) soil treated with compost at application rates of 15,45 , and $90 \mathrm{tha}^{-1}$; (SS) soil treated with sewage sludge at application rates of 15, 45, and $90 \mathrm{tha}^{-1}$. Average \pm S.D.; where absent, bars fall within symbols.

due to the addition of compost at high application rate of $90 \mathrm{tha}^{-1}$, this increase of metabolic activity was not found as incubation time increased; mainly due to the added material's stability with composting. This fact suggested that not only the amount of TOC added to the soil, but also the quality of the organic matter affected 
TABLE V

Effect of organic wastes on dynamics of $q \mathrm{CO}_{2}$ ( $\mathrm{mg} \mathrm{CO} \mathrm{CO}_{2}-\mathrm{C} \mathrm{h}^{-1} \mathrm{~g}$ biomass $\mathrm{C}$ ) during the incubation experiment

\begin{tabular}{|c|c|c|c|c|c|}
\hline \multirow{2}{*}{$\begin{array}{l}\text { Application } \\
\text { rate }\left(\mathrm{t} \mathrm{ha}^{-1}\right)\end{array}$} & \multicolumn{5}{|c|}{ Incubation time (days) } \\
\hline & 0 & 27 & 60 & 90 & LSD \\
\hline \multicolumn{6}{|c|}{ Compost treatment } \\
\hline 15 & 7.5 & 3.2 & 2.2 & 1.8 & 0.9 \\
\hline 45 & 9.0 & 2.4 & 2.0 & 1.9 & 0.7 \\
\hline 90 & 10.2 & 2.2 & 2.0 & 2.0 & 1.6 \\
\hline \multicolumn{6}{|c|}{ Sewage sludge treatment } \\
\hline 15 & 12.1 & 2.5 & 2.0 & 1.8 & 0.8 \\
\hline 45 & 13.8 & 4.9 & 4.1 & 4.4 & 0.9 \\
\hline 90 & 15.1 & 5.2 & 4.4 & 5.4 & 0.5 \\
\hline \multicolumn{6}{|c|}{ Control treatment } \\
\hline- & 7.8 & 3.7 & 2.8 & 1.4 & 2.5 \\
\hline \multicolumn{6}{|c|}{ LSD treatment } \\
\hline & 2.2 & 0.4 & 0.3 & 0.7 & \\
\hline
\end{tabular}

the metabolic quotient (Leita et al., 1999). Pascual et al. (1997) found that the metabolic quotient was higher after the addition of sewage sludge and municipal solid waste than after compost addition.

\subsection{EFFECT OF ORGANIC WASTES AND INCUBATION TIME ON DYNAMICS OF MOBILE FRACTIONS OF HEAVY METALS}

In our soil, the total content of heavy metals $(\mathrm{Zn}, \mathrm{Cd}, \mathrm{Cu}, \mathrm{Pb}$, and $\mathrm{Ni}$ ) can be considered as normal for a non-contaminated soil (Table I). Scheffer and Schachtschabl (2002) gave the following values of heavy metals in non-contaminated soil: 10-80 ppm for $\mathrm{Zn}, 0.1-0.5 \mathrm{ppm}$ for $\mathrm{Cd}, 2-40 \mathrm{ppm}$ for $\mathrm{Cu}, 5-50 \mathrm{ppm}$ for $\mathrm{Ni}$, and 2-60 ppm for $\mathrm{Pb}$. The heavy metals extracted with $\mathrm{NH}_{4} \mathrm{NO}_{3}$ give an indication of the heavy metals included in the mobile fraction of the soil (Zeien and Brümmer, 1989). The percentages of $\mathrm{NH}_{4} \mathrm{NO}_{3}$-extractable $\mathrm{Zn}, \mathrm{Cd}, \mathrm{Cu}, \mathrm{Ni}$, and $\mathrm{Pb}$ were calculated with respect to their total content (Figure 4). Soils act as buffer systems, and can immobilize heavy metals. The degree of buffering depends both on the kind of heavy metal and the soil (Welp, 1989, 1999). Our results showed that the initial percentage of heavy metals extracted with $\mathrm{NH}_{4} \mathrm{NO}_{3}$ lay in the range of $0-29 \%$ of the total content. This percentage differs from one heavy metal to another depending on its mobility. The order of mobility of the heavy metals was: $\mathrm{Cd}>\mathrm{Cu}>\mathrm{Ni}>\mathrm{Pb}>\mathrm{Zn}$. During the three months of incubation, the mobility of heavy metals showed significant changes for all treatments. Most changes in extractability of mobile heavy metals occurred at 

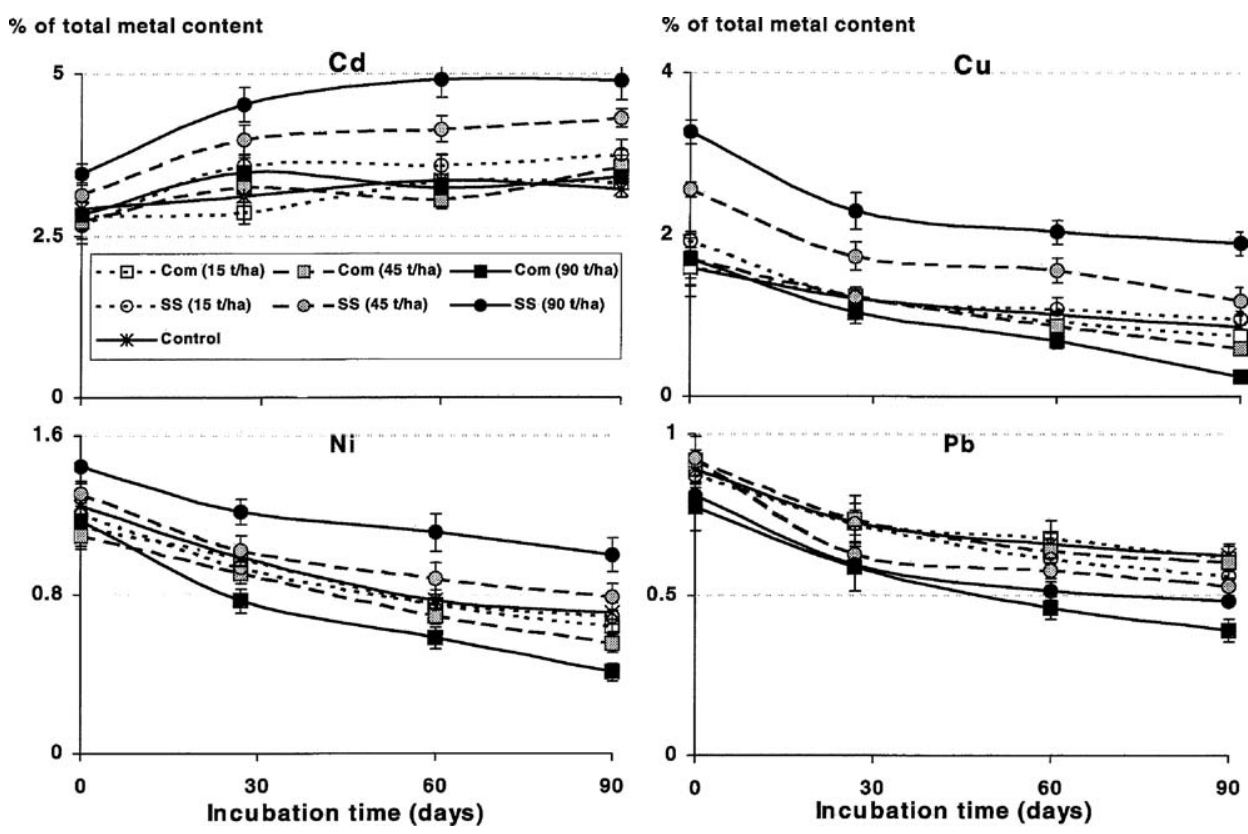

Figure 4. Effect of organic wastes on dynamics of mobile fraction of heavy metals during the incubation experiment. Control soil; (com) soil treated with compost at application rates of 15, 45, $90 \mathrm{tha}^{-1}$; (SS) soil treated with sewage sludge at application rates of 15, 45, and $90 \mathrm{t} \mathrm{ha}^{-1}$. Average \pm S.D.; where absent, bars fall within symbols.

high application rates of sewage sludge and compost. Among all treatments, the soil treated with sewage sludge showed a significant increase in extractability of mobile $\mathrm{Cd}, \mathrm{Cu}, \mathrm{Zn}$ and $\mathrm{Ni}$ as compared to the control, especially with the highest application rate. In contrast, the addition of sewage sludge at 45 and $90 \mathrm{t} \mathrm{ha}^{-1}$ caused a significant decrease in mobile $\mathrm{Pb}$ compared to the control. Possible explanations for the increase of mobile $\mathrm{Zn}, \mathrm{Cd}, \mathrm{Cu}$, and $\mathrm{Ni}$ in soil amended with sewage sludge are: (i) the high content of heavy metals in sewage sludge; (ii) formation of soluble heavy metals-organic associations (iii) the decrease in soil pH. Sloan et al. (1997) found that the application of sewage sludge increased the percentages of $\mathrm{Ni}, \mathrm{Zn}$, and $\mathrm{Cd}$ in the exchangeable fraction. Chander et al. (1995) noted that the amounts of $\mathrm{Cd}, \mathrm{Zn}$, $\mathrm{Ni}$ and $\mathrm{Cu}$ extracted with $0.5 \mathrm{M} \mathrm{K}_{2} \mathrm{SO}_{4}$ increased with increasing sludge application rate. Our results showed that the addition of sewage sludge led to a reduction in soil $\mathrm{pH}$ and an increase in water dissolved organic $\mathrm{C}$ and fulvic acid $\mathrm{C}$. This result confirms that the mobility of heavy metals can be increased by the addition of sewage sludge. Several investigations have revealed that soluble organics are able to raise the mobility of heavy metals (Temminghoff et al., 1998; Amrhein et al., 1992; Neal and Sposito, 1986). McBride (1995) reported that heavy metal complexes with fulvic acids are soluble. The soil $\mathrm{pH}$ has also been shown to govern the concentrations of soluble and plant available heavy metals (Brallier et al., 1996). Heavy metal 
solubility increases at lower $\mathrm{pH}$ and decreases at higher $\mathrm{pH}$ values (Chuan et al., 1996). In our investigation, the soil treated with compost at high application rate showed the lowest mobility of $\mathrm{Cu}, \mathrm{Ni}$, and $\mathrm{Pb}$ during the incubation experiment. This result suggests that the quality of organic matter affects the availability and mobility of heavy metals. It is widely known that the availability of heavy metals in soil is strongly influenced by the amount and the quality of organic matter which can interact with the heavy metals, forming complexes and chelates of varying stability (Leita et al., 1999). At the end of the incubation (90 days), mobile $\mathrm{Cu}, \mathrm{Ni}$, and $\mathrm{Pb}$ decreased significantly from $0.85 \%, 0.70 \%$ and $0.62 \%$ of total content for the control to $0.24 \%, 0.41 \%$ and $0.39 \%$ of their total content for the soil treated with compost at the highest application rate, respectively. It was observed that the highest decrease was pronounced for $\mathrm{Cu}$. In this connection, organic matter from compost may have a significant impact on reducing $\mathrm{Cu}$ availability. Many studies have shown that copper has the ability to form strong complexes with organic matter (Van Dijk, 1971; McBride, 1978; Tyler and McBride, 1982). The importance of soil organic mater in limiting $\mathrm{Pb}$ availability has also been demonstrated (Strawn and Sparks, 2000). Brown et al. (2003) reported that the application of biosolids composts effectively reduced the $\mathrm{Pb}$ availability. For all treatments, the mobility of $\mathrm{Cu}, \mathrm{Ni}, \mathrm{Zn}$, and $\mathrm{Pb}$ decreased as incubation time increased. This is attributed to the tendency of soluble $\mathrm{Cu}, \mathrm{Ni}, \mathrm{Zn}$, and $\mathrm{Pb}$ to be precipitated by $\mathrm{CaCO}_{3}$ in calcareous soil or to bind with the organic matter due to the addition of sewage sludge and compost.

The concentration of the mobile fraction of $\mathrm{Zn}$ in this soil was actually below the detection limit $\left(0.01 \mathrm{mg} \mathrm{L}^{-1}\right)$ of the ASS instrument. This result indicates that $\mathrm{CaCO}_{3}$ in soils led to $\mathrm{Zn}$ precipitation as $\mathrm{ZnCO}_{3}$. Osman et al. (1980) demonstrated that $\mathrm{CaCO}_{3}$ plays an important role in $\mathrm{Zn}$ deficiency which is found in Egypt's calcareous soils. Morera et al. (2002) found that the availability of $\mathrm{Zn}$ was remarkably low in soil with high carbonate content. In this investigation, however, the addition of sewage sludge at 45 and $90 \mathrm{tha}^{-1}$ raised the initial extractability of mobile $\mathrm{Zn}$ by $0.08 \%$ and $0.11 \%$ of total content, respectively (data not shown). This result concurs with that of Almas et al. (2000) who found that addition of organic matter increased the solubility of $\mathrm{Zn}$ by formation of organo-metallic complexes. Our result provides good evidence that the mobilization of unavailable zinc in calcareous soil can be increased by the addition of sewage sludge. It was observed that the initial increase of extractable $\mathrm{Zn}$ decreased with increasing incubation time. Among heavy metals, the highest mobility was found for $\mathrm{Cd}$ with addition of sewage sludge. The initial extractability of mobile Cd increased significantly up to 27 days of incubation in the soil treated with sewage sludge. After that, the extractability of mobile Cd almost remained constant up to the end of the incubation. At the end of incubation (90 days), mobile cadmium increased significantly from $3.2 \%$ of total content for control to $3.7 \%, 4.3 \%$ and $4.9 \%$ of total content for soil amended with sludge at application rates of 15,45 , and $90 \mathrm{th}^{-1}$, respectively. This increase of mobility of $\mathrm{Cd}$ can be due to the mineralization of $\mathrm{Cd}$ from organic sewage sludge or the formation of soluble organo-metallic complexes. It is possible that high DOC concentrations 
in soil treated with sewage sludge inhibited precipitation of Cd (Sloan et al., 1997). Holm et al. (1996) found that DOC inhibited precipitation of $\mathrm{CdCO}_{3}$ in agriculture soil. Neal and Sposito (1986) reported that the solid soil sorption of Cd was reduced by the formation of soluble-organic associations in the aqueous solution. Our results suggest that sewage sludge-applied Cd is easy to extract from soil and can be available for plants. In contrast, the mobility of $\mathrm{Cd}$ was unaffected by the addition of compost as compared to untreated soil.

\section{Conclusion}

The addition of organic wastes (sewage sludge and compost) to the calcareous soil increased the values of dissolved organic $\mathrm{C}$, humic substances $\mathrm{C}, \mathrm{C}_{\text {org }}$ mineralization, microbial biomass $\mathrm{C}$, and $q \mathrm{CO}_{2}$. The $\mathrm{C}_{\text {org }}$ mineralization is related with decrease of $\mathrm{C} / \mathrm{N}$ ratio during the incubation experiment. The addition of sewage sludge at high application rate caused a high decrease in soil $\mathrm{pH}$ of approximately $(0.55-0.66)$. Our result provided good evidence that the mobilization of unavailable $\mathrm{Zn}$ in calcareous soil can be increased by the addition of sewage sludge. Both sewage sludge and compost addition enhanced the studied biochemical properties of calcareous soil. However, the addition of sewage sludge at high application rate led to a high increase in soil salinity and extractability of $\mathrm{Cd}, \mathrm{Ni}$, and $\mathrm{Cu}$. The high EC and extractability of heavy metals in sludge amended soil at high sludge application rate may pose an inhibitory effect on plant growth in calcareous soil. This reason may limit the use of sewage sludge as amendments for calcareous soil. Therefore, more studies are needed to investigate the effect of sewage sludge on plant growth and uptake of heavy metals under field condition.

\section{Acknowledgements}

We would like to thank G. Scholich for linguistic help. This work was partly funded by Egyptian government in the scope of fellowship for A.R.A. Usman.

\section{References}

Almas, A.R., McBride, M.B. and Singh, B.R.: 2000, 'Solubility and lability of cadmium and zinc in two soils treated with organic matter', Soil Sci. 165, 250-259.

Amrhein, C., Strong, J.E. and Mosher, P.A.: 1992, 'Effect of deicing salts on metal and organic matter mobility in roadside soils', Environ. Sci. Technol. 26, 703-709.

Anderson T. and Domsch, K.H.: 1993, 'The metabolic quotient for $\mathrm{CO}_{2}\left(\mathrm{qCO}_{2}\right)$ as a specific activity parameter to asses the effects of environmental conditions, such as $\mathrm{pH}$, on the microbial biomass of the soil', Soil Biol. Biochem. 25, 393-395.

Anderson, J.P.E. and Domsch, K.H.: 1978, 'A physiological method for the quantitative measurement of microbial biomass in soil', Soil Biol. Biochem. 10, 215-221.

Berrow, M.L. and Webber, J.: 1972, 'Trace elements in sewage sludges', J. Sci. Food Agric. 23, 93-100. 
Black, C.A. 1965.: Methods of Soil Analysis, American Society of Agronomy, Inc., Madison, Wisconsin, USA.

Brallier, S., Harrison, R.B., Henry, C.L. and Dongsen, X.: 1996, 'Liming effects on availability of $\mathrm{Cd}, \mathrm{Cu}, \mathrm{Ni}$, and $\mathrm{Zn}$ in a soil amended with sewage sludge 16 years previously', Water Air Soil Pollut. 86, 195-206.

Brown, S., Chaney, R.L., Hallfrisch, J.G. and Xue, Q.: 2003, 'Effect of biosolids processing on lead bioavailability in an urban soil', J. Environ. Qual. 32, 100-108.

Chander, K. and Brookes, P.C.: 1991, 'Effects of heavy metals from past applications of sewage sludge on microbial biomass and organic matter accumulation in a sandy loam and silty loam U.K. soil', Soil Biol. Biochem. 23, 927-932.

Chander, K., Brookes, P.C. and Harding, S.A.: 1995, 'Microbial biomass dynamic following addition of metal-enriched sewage sludge to a sandy loam', Soil Biol. Biochem. 27, 14091421.

Chander, K., Dyckmans, J., Joergensen, R.G., Meyer, B.and Raubuch, M.: 2001, 'Different sources of heavy metals and their long-term effects on soil microbial properties', Biol. Fertil. Soils 34, 241-247.

Chuan, M.C., Shu, G.Y. and Liu, J.C.: 1996, 'Solubility of heavy metals in a contaminated soil: Effects of redox potential and $\mathrm{pH}$ ', Water Air Soil Pollut. 90, 543-556.

Friedel, J.K., Langer, T., Siebe, C. and Stahr. K.: 2000, 'Effects of long-term waste water irrigation on soil organic matter, soil microbial biomass and its activities in central Mexico', Biol. Fertil. Soils 31, 414-421.

Goyal, S., Mishra, M.M., Dhankar, S.S., Kapoor, K.K. and Batra, R.: 1993, 'Microbial biomass turnover and enzyme activities following the application of farmyard manure to field soils with and without previous long-term applications', Biol. Fertil. Soils 15, 60-64.

Holm, P.E., Anderson, B.B.H. and Christensen, T.H.: 1996, 'Cadmium solubility in aerobic soils', Soil Sci. Soc. Am. J. 60, 775-780.

Jin, Q., Zi-jian, W., Xiao-quann, S., Qiang, T., Bei, W. and Bin, C.: 1996, 'Evaluation of plant availability of soil trace metals by chemical fractionation and multiple regression analysis', Environ. Pollut. 91, 309-315.

Johansson, M., Stenberg, B. and Torstensson, L.: 1999, 'Microbiological and chemical changes in two arable soils after long-term sludge amendments', Biol. Fertil. Soils 30, 160-167.

Jörgensen, R.G.: 1996, 'The fumigation-extraction method to estimate soil microbial biomass: Calibration of the kEC value', Soil Biol. Biochem. 28,25-31.

Kiikilä, O., Pennanen, T., Perkiömäki, J. and Derome, J.: 2002. 'Organic material as a copper immobilizing agent: A microcosm study on remediation', Basic Appl. Ecol. 3, 245-253.

Leifeld, J., Siebert, S. and Kögel-Knabner, I.: 2002, 'Biological activity and organic matter mineralization of soil amended with biowaste composts', J. Plant Nutr. Soil Sci. 165, 151159.

Leita, L., De Nobili, M., Muhlbachova, G., Mondini, C., Marchiol, L. and Zerbi, G.: 1995, 'Bioavailability and effects of heavy metals on soil microbial biomass survival during laboratory incubation', Biol. Fertil. Soils 19, 103-108.

Leita, L., Nobili, M.D. and Mondini, C.: 1999, 'Influence of inorganic and organic fertilization on soil microbial biomass, metabolic quotient and heavy metal bioavailability', Biol. Fertil. Soils 28 , 371-376.

McBride, M.B.: 1978, 'Transition metal bonding in humic acid: An ESR study', Soil Sci. 126, 200209.

McBride, M.B.: 1995, 'Toxic metal accumulation from agriculture use of sludge: Are USEPA regulations protective?', J. Environ. Qual. 24, 5-18.

McBride, M., Sauve, S. and Hendershot, W.: 1997, Solubility control of $\mathrm{Cu}, \mathrm{Zn}, \mathrm{Cd}$, and $\mathrm{Pb}$ in contaminated soil', Eur. J. Soil Sci. 48, 337-346. 
Moolenaar, S.W. and Beltrami, P.: 1998, 'Heavy metal balances of an Italian soil as affected by sewage sludge and Bordeaux mixture applications', J. Environ. Qual. 27, 828-835.

Moreno, J.L., Hernandez, T. and Garcia, C.: 1999, 'Effects of a cadmium-contaminated sewage sludge compost on dynamics of organic matter and microbial activity in an arid soil', Biol. Fertil. Soils 28, 230-237.

Morera, M.T., Echeverria, J. and Garrido, J.: 2002, 'Bioavailability of heavy metals in soils amended with sewage sludge', Can. J. Soil Sci. 82, 433-438.

Neal, R.H. and Sposito, G.: 1986, 'Effects of soluble organic matter and sewage sludge amendments on Cd sorption by soils at low Cadmium concentrations', Soil Sci. 142, 164-172.

Osman, A.Z., Wassif, M.M., El-Kadi, M.A. and Abdel Salam, M.A.: 1980, 'Effect of carbonate in clay fraction on fixation of zinc', Z. Pflanzenernähr. Bodenkdl. 143, 524-529.

Pascual, J.A., Garcia, C. and Hernandez, T.: 1999, 'Lasting microbiological and biochemical effects of the addition of municipal solid waste to an arid soil', Biol. Fertil. Soils 30, 1-6.

Pascual, J.A., Garcia, C., Hernandez, T. and Ayuso, M.: 1997, 'Changes in the microbial activity of an arid soil amended with urban organic wastes', Biol. Fertil. Soils 24, 429-434.

Powlson, D.S., Brookes, P.C. and Christensen, B.T.: 1987, Measurements of soil microbial biomass provides an early indication of changes in total soil organic matter due to straw incorporation', Soil Biol. Biochem. 19, 159-164.

Richards, L.A.: 1960, Diagnosis and Improvement of Saline and Alkaline Soils, U.S. Salinity Laboratory, Agricultural handbook No. 60.

Scheffer, F. and Schachtschabel, P.: 2002, Lehrbuch der Bodenkunde, 15. Auflage. Spektrum Akademischer Verlag Heidelberg. Berlin.

Schlichting, E., Blume, H.P. and Stahr, K.: 1995, Bodenkundliches Praktikum, 2nd edn. Blackwell, Berlin.

Silveira, M.L.A., Alleoni, L.R.F. and Guilherme, L.R.G.: 2003, 'Review: Biosolids and heavy metals in soils', Scientia Agricola 60, 793-806.

Sloan, J.J. and Basta, N.T.: 1995, 'Remediation of acid soils by using alkaline biosolids', J. Environ. Qual. 24, 1097-1103.

Sloan, J.J., Dowdy, R.H., Dolan, M.S. and Linden, D.R.: 1997, 'Long-term effects of biosolids applications on heavy metal bioavailability in agriculture soils', J. Environ. Qual. 26, 966974.

Speir, T.W., van Schaik, A.P., Lloyd-Jones, A.R. and Kettles, H.A.: 2003, 'Temporal response of soil after cultivation following high application rates of undigested sewage sludge', Biol. Fertil. Soils 38, 377-385.

Strawn, D.G. and Sparks, D.L.: 2000, 'Effects of soil organic matter on the kinetics and mechanisms of $\mathrm{Pb}$ (II) sorption and desorption in soil', Soil Sci. Soc. Am. J. 64, 144-156.

Temminghoff, E.J.M., van der Zee, S.E.A.T.M. and De Haan, F.A.M.: 1998, 'Effects of dissolved organic matter on the mobility of copper in a contaminated sandy soil', Eur. J. Soil Sci. 49, $617-628$.

Tyler, L.D. and McBride, M.B.: 1982, 'Mobility and extractability of cadmium, copper, nickle, and zinc in organic and mineral soil columns', Soil Sci. 134, 198-205.

Van Dijk, J.: 1971, 'Cation binding of humic acids', Geoderma 5, 53-67.

Vance, E.D., Brookes, P.C. and Jenkinson, D.S.: 1987, 'An extraction method for measuring microbial biomass C', Soil Biol. Biochem. 19, 703-707.

Wang, P., Qu, E., Li, Z. and Shuman, L.M.: 1997, 'Fractions and availability of nickel in loessial soil amended with sewage or sewage sludge', J. Environ. Qual. 26, 795-801.

Welp, G.: 1989, 'Löslichkeit und Bioverfügbarkeit von Umwelt-Chemikalien in Böden unterschiedlichen Stoffbestandes', Mitteilgn. Dtsch. Bodenkdl. Ges. 59, 43-52.

Welp, G.: 1999, 'Inhibitory effects of the total and water-soluble concentrations of nine different metals on the dehydrogenase activity of a loess soil', Biol. Fertil. Soils 30, 132-139. 
Wong, J.W.C., Lai, K.M., Su, D.S. and Fang, M.: 2001, 'Availability of heavy metals for Brassica Chinensis growth in an acidic loamy soil amended with a domestic and an industrial sewage sludge', Water, Air Soil Pollut. 128, 339-353.

Wu, J., Jörgensen, R.G., Pommerening, B., Chaussod, R. and Brookes, P.C.: 1990, 'Measurement of soil microbial biomass $\mathrm{C}$ by fumigation-extraction — an automated procedure', Soil Biol.Biochem. 22, 1167-1169.

Zeien, H. and Brümmer, G.W.: 1989, 'Chemische Extraktionen zur Bestimmung von Schwermetallbindungsformen in Böden', Mitteilgn. Dtsch. Bodenkdl. Ges. 59, 505-510. 